\title{
Islamic Fintech: Archaeology of a Discourse
}

\author{
Abderrazak Belabes ${ }^{1}$
}

Corresponding email: abelabes@kau.edu.sa

\begin{abstract}
The objective of this paper is to present an archaeology of the discourse on Islamic fintech to highlight its mimetic character, i.e. the desire to imitate globalized finance to obtain the same thing in terms of prestige. The archaeology of the discourse revealed the following: (i) The difference between the classic Islamic conception of finance and Islamic fintech lies in the mobilization of digital technology innovation in the field of finance. (ii) The difference between Islamic fintech and conventional fintech lies in the compatibility of Islamic financial products and services with Maqāșid al-Sharīah. After shedding light on the themes of social innovation and slow technology, the study recommends paying special attention to the notion of design thinking in the sense that it offers the opportunity to imagine solutions through the intersection of analysis, intuition, experimentation, and human connection. It is imperative to invest in local startups to innovate solutions that meet both the needs of users and the ambitions of organizations, while taking care not to destroy social structures, and allowing each person to develop its own specific world (milieu, Umwelt, fûdo 風土).
\end{abstract}

Keywords: Archaeology of knowledge; Islamic fintech; Innovation; Design thinking JEL Classification: A13; G10; 033; O35

Type of paper: Research Paper

@ IJIEF 2022 published by Universitas Muhammadiyah Yogyakarta, Indonesia

DOI:

Web:

https://doi.org/10.18196/ijief.v5i1.11248 https://journal.umy.ac.id/index.php/ijief/article/view/11248

\section{Citation:}

Belabes, A. (2022). Islamic fintech: Archaeology of a discourse. International Journal of Islamic Economics and Finance (IJIEF), 5(1), 129-150, DOI: https://doi.org/10.18196/ijief.v5i1.11248

\footnotetext{
${ }^{1}$ King Abdulaziz University, Saudi Arabia
} 
Belabes | Islamic Fintech: Archaeology of a Discourse

\section{Introduction}

\subsection{Background}

For those who are in regular contact with Islamic finance circles and meditate their discourse without preconceived ideas or ideological bias under the effect of mirror game, the more time goes by, the more this discourse seems to be assimilated to something light, i.e., empty of substance, meaning, and difference worthy of interest. Some actors are on the lookout for trending topics to add the adjective 'Islamic' or the word 'from Islamic perspective'. With a wave of a magic wand, everything becomes Islamic: development, competitiveness, wealth, social finance, cryptocurrency, crowdfunding, benchmarking, E-commerce, fintech. This fever, even if it gives the impression of unequaled success or a stroke of genius, will sooner or later fade away like all fashions. Allah says in the Qur'ān: (The worthless residue is then cast away, but what benefits people remains on the earth) [Sourat 13, Verse 17]. Above all, it reveals a level of reading that is limited to form without rising to the quest for the substance to explore the underlying epistemological presuppositions.

In this context, the study draws the attention of researchers and practitioners to rise to this level of meditation of what is fashionable in Islamic finance circles with their feet on the ground without fascination or rejection. To this end, it proposes an archaeology of knowledge having for object the discourse on Islamic fintech. This leads in filigree to the need to question the status of Islamic finance as an academic discipline, its history as a field of knowledge that claims to be Islamic, and the concepts that structure it as a system on both a theoretical and practical level. In this little game of imitating the products and services of mainstream finance, customers will not be fooled for long. Sooner or later they will turn to the conventional, as people generally prefer the original to the copy. In this case, it will not be easy to regain the trust and loyalty of customers. The stakes are momentous, it is therefore important not to take lightly.

In 1952 and 1953, the famous English historian Arnold Toynbee gave two lectures at the Gifford Lectures on the historian's approach to religion. They have been grouped into a book An Historian's Approach to Religion, published in 1956 by Oxford University Press. In this fascinating book, he develops the idea that technology, first conceived as a substitute for religious fanaticism, has finally taken the place of religion (Toynbee, 1963, p.215). In another book A Study of History, he has often defended the idea that "religion is a permanent reality that cannot be extracted from human nature" (Toynbee, 1978, p.503). The need to believe is inherent in human nature regardless of the form of religious sentiment. For the American historian George Dyson 
Belabes | Islamic Fintech: Archaeology of a Discourse

(2016), who considers himself more as a historian of people who have a connection with technology than as a historian of technology, technology has the qualities that human beings seek in religion. Far from having disappeared, the latter has been metabolized in faith in technological progress, as noted by the critical technology historian David F. Noble (1999) in his book The religion of technology. These insightful analyses show the limits of slogans that circulate on social networks like: The Impact of The Digital Revolution on Religion, How Religion and Technology Coexist in a Digital Age, Religion in the Age of Digitalization.

In this context of restructuring, where secularization does not mean the end of religiosity (Simmel, [1912]1998, p.153), how can we explain that people who proclaim themselves as Muslims believe that technology will have the answer to everything concerning their field of activity, in this case: finance? In workshops and seminars dedicated to Islamic fintech, the merits of crowdfunding, blockchain, cryptocurrencies, disruptive technology are often praised. This question of the interpenetration of beliefs reveals the coexistence of two worlds in everyday life: that of worship (din) and that of business (dunyā). It raises an underlying question about the real effect of ritual practice on the conduct of personal affairs. The interweaving of religion and economy through digital technology remains to be studied beyond fashionable themes such as The New Spirit of Capitalism (Boltanski \& Chiapello, 1999) or Market Islam (Haenni, 2006), which have been overtaken by events due to lack of lucidity.

\subsection{Objective}

The aim of the study is to invite researchers not to jump on the fashionable discourses, which are comparable to bubbles that always end up deflating. From my humble experience as an economic analyst and my background as an electronic engineer, I have found that most people who use the word Islamic Fintech do not understand its true meaning or its real significance in terms of non-neutrality of technique, despite the good intentions and fine declarations regularly expressed. Fintech, the marketing abbreviation for financial technology, refers to new technologies that aim to improve and automate financial services. In a more down-to-earth manner, when talking about fintech, for a long time there was a tendency to consider, on the one hand, many innovative startups looking for users and, on the other hand, large financial players, well established in the market but lacking innovation. This dichotomous vision should gradually be blurred as the two worlds come together, which may restrict competition through tacit agreements and further increase inequalities that most Islamic finance players are not paying attention. 
Belabes | Islamic Fintech: Archaeology of a Discourse

After the literature review which shows that this study is the first of its kind and denotes the difficulty of the task, it is about presenting an archaeology of the discourse on Islamic fintech as a practice that systematically forms the object of which it speaks. The aim is not to neutralize the discourse but to maintain its consistency, to make it emerge in its own complexity. This archeology allows us to grasp the epistemological presuppositions that work in people's minds like a religion, because the discourse on fintech promises paradise on earth, constantly improving the future of mankind, offering new services, more accessible, of better quality, and at a lower cost. The study then critically analyzes MIT's engineering equation of innovation, which is used as an authoritative reference in the specialized literature. The study then proposes a deconstruction of the notion of innovation, discusses the importance of the notion of social innovation and that of slow technology. The conclusion outlines the main results of the study in terms of exploring the underlying epistemological presuppositions before presenting the recommendations.

\section{Literature Review}

\subsection{Background Theory}

The archaeology of the knowledge, as a critical method of discourse (Foucault, 1969), consists in an uncovering of the conceptual strata of a knowledge perceived as constituted (Belabes, 2001), under the effect of the Cartesian dualism of the subject and the object (Descartes, 2008, p.38-39). It leads to the deciphering of texts to detect a plurality of levels, and to the interrogation of discourses to discover the secret movements of thought, and to put the finger on the unspoken or the background of the discursive context beyond the smokescreen formed by conceptual intermediaries (notions, dichotomies, classifications) and technical tools (mathematics, statistics, probabilities, artificial intelligence, big data) (Belabes, 2019a). These intermediaries and tools are elements of the discourse rather than means to elaborate a picture of reality in a rigorous way (Bouleau, 2014). They are oriented towards control, quantitative, and reductionism rather than towards the invention and construction of understandings (Supiot, 2015). This deficiency is evident in the design of master programs dedicated to fintech and Islamic fintech. Designers would still need to have the means to grasp the subtleties to distinguish the substance from the form and the essential from the accessory (Belabes, 2021). 


\subsection{Previous Studies}

In view of the above, it appears that this is the first study of its kind ever undertaken, not only because of the difficulty of the subject, the archaeology of knowledge, which requires extensive and specific knowledge of epistemology, in the broadest sense of the term: How do we know what we think we know? But also because of the difficulty to step back from what is fashionable: fintech. If a subject becomes fashionable, it is a disaster in terms of knowledge. The reason is that fashion is the false intelligence that spoils everything original in human and social sciences that are essential for a better understanding of the world and of oneself, in particular literature, history, anthropology, ethology, and mesology. Taking care not to artificially separate these fields of knowledge, all related to the academic world, which wants distinctions everywhere.

\section{Methodology}

\subsection{Data}

The term data designates here something crude which serves as a basis for reasoning, examination, or research. In this sense, the data has been collected from various sources that are part of the discourse on Islamic fintech, including recent publications most of which only repeat what is said on the internet and on social networks.

\subsection{Method}

In Islamic finance circles, the major problem in the discourse on fintech is the lack of knowledge and the lack of technical mastery. That is a problem when people do not even understand what they are trying to promote apart from what is circulating on the Internet and on social networks. This explains why I resigned myself to deal with discourse and not with in-depth knowledge. Archeology of knowledge practiced as a method of approaching the discourse on Islamic fintech strives to raise the level of analysis for the benefit of those who will be interested in the subject in the future with a real desire to deepen their knowledge.

\section{Result and Discussion}

\subsection{Archaeology of The Discourse on Islamic Fintech}

At the end of his speech "Enabling the FinTech transformation: Revolution, Restoration, or Reformation", delivered on 16 June 2016, Mark Carney, the 
Belabes | Islamic Fintech: Archaeology of a Discourse

Governor of the Central Bank of England, and Chairman of the Financial Stability Board (FSB) which promotes international financial stability, said: "With time, FinTech could mean a more open, more transparent, and more democratic global financial system" (Carney, 2016, p.11).

But what is fintech in the eyes of regulators? It is innovation in financial services (de Vauplane, 2015, p.29). This is evidenced by the words of Gérard Rameix, President of the French Financial Markets Authority, in a speech to the FinTech Forum, organized by the Financial Markets Authority (AMF) and The Prudential Supervision and Resolution Authority (ACPR): "We are living in a period of extraordinary financial innovation, perhaps even unprecedented" (Rameix, 2016). The portal of the French Ministry of Economy (2018) notes in a thematic note entitled Fintech, digital technology serving the financial sector of the economy that fintech "refers to small enterprises (start-ups and SMES) that provide financial services through innovative solutions. The fields of application are varied: mobile payment, crowdfunding, savings management, insurance and credit, online financial advice, decision support using algorithms".

The discourse on Islamic fintech is in line with the same approach, under the influence of mimetic rivalry, despite the argument that the implementation of digital technologies within the spirit of Maquașid al-Sharìah should stimulate the development of Islamic finance by increasing the accessibility of banking and other financial services in Islamic communities around the world and by making it easier to access investment opportunities in different sectors (Ali et al., 2021). At the same time, digital technologies will increase financing opportunities and facilitate asset management for companies that consider Islamic business ethics (Sánchez Fernández, 2021).

The same remark is true for the argument that refers to the effects and implications of rapidly evolving digital technologies on Islamic finance in terms of SWOT analysis (strengths, weaknesses, opportunities, and threats) (Billah, 2021). This denotes a glaring lack of underlying epistemological presuppositions of both digital technology and SWOT analysis. Indeed, in strategic management there are three major strategies: adapt to the market, influence the market, create a new market. SWOT analysis is part of the first strategy, which is to adapt to the market. In contrast, the digital world refers to disruptive technology that replaces a dominant technology in a market. In this sense, associating digital technology with SWOT analysis is an oxymoron that aims to bring together two terms that their underlying epistemological presuppositions should keep apart. Discourse, thus conceived, is not the majestically unrolled manifestation of a subject that thinks, knows, and says it. On the contrary, it is an ensemble where the dispersion of the subject and its discontinuity with itself can be determined (Foucault, 1969, p.74). But it is 
Belabes | Islamic Fintech: Archaeology of a Discourse

still necessary that this in-depth analysis is within the reach of the understanding of the followers of the discourse on fintech who usually just copy and paste what is in vogue, especially in the Covid-19 period (Rabbani et $a l, 2021)$, without a critical mind. The value of a technique is not measured by its ability to solve a problem posed by an event phenomenon of which no one is able to really understand the ins and outs. Despite the most sophisticated risk management models, the history of the technique shows that men remain prisoners of the boxes they make to enclose the ailments that appear to them to be the most dangerous. Hence the need for an approach to maqāșid under the prism of the non-neutrality of technique (Belabes, 2021a).

If in the mainstream fashion discourse in Silicon Valley a disruptive technology is an innovation that significantly changes the way the existing market operates, the question here is: Why the discourse on digital technology is more typically associated with innovation by excluding "other forms of enunciation" (Foucault, 1969, p.40)? This archeology of discourse leads to exploring the meaning of innovation in engineering schools with reference to the MIT, Massachusetts Institute of Technology, which has a place in the ranking of the world's best-known and most prestigious universities specializing in science and technology.

\subsection{Criticism of The MIT's Engineering Equation of Innovation}

In the MIT's classrooms, Edward B. Roberts taught his students for many years the equation (1)

$$
\text { Innovation = Invention }+ \text { Commercialization }
$$

In his paper Managing invention and invention, widely published in the literature on the subject, Roberts (1988, p.12-13) wrote: "Innovation is composed of two parts: (1) the generation of an idea or invention, and (2) the conversion of that invention into a business or other useful application. Using the generally accepted (broad) definition of innovation-all of the stages from the technical invention to final commercialization- the technical contribution does not have a dominant position (3). This leads me to a simple definition of my own, but nonetheless, one I feel is critical to emphasize:

$$
\text { Innovation = Invention + Commercialization" }
$$

Equation (2) is used in the introductory courses on innovation at MIT (Aulet, 2013) and the MIT history and observations on entrepreneurship and innovation (Estabil, 2012, p.5). For Kenneth Morse (2013), founder and CEO of the MIT Entrepreneurship Center for thirteen years, "innovation is invention plus commercialization. It's very important to understand that creating new ideas and new technologies is important, but we also need commercialization". 
Belabes | Islamic Fintech: Archaeology of a Discourse

This gives an idea of the definition of invention at MIT:

$$
\text { Invention }=\text { New Ideas }+ \text { New Technologies }
$$

Some researchers prefer to define innovation as the commercialization of a new idea (Fagerberg, 2003, p.3), or the conversion of a new idea into revenues and profits (Lafley, Charan, 2008, p.21), on the basis that an idea is the original elaboration of thought, for responding to a situation, to be at the origin of an original action, work, or invention. For others, innovation is the creation of a new product-market-technology-organization-combination (Boer, During, 2001, p.84).

In the academic circles, inventions as intellectual assets are generally transformed into intellectual property, via such mechanisms as patents, licenses, copyrights, and trademarks. Equation (3) is written as follows:

$$
\text { Innovation }=\text { Intellectual Property }+ \text { Commercialization }
$$

Innovation and invention are concepts that one might think are synonymous, but that cut across different realities. Thus, it is inventions that can be protected by intellectual property rules and not innovations, hence the term patent. Often associated with the term innovation, the invention is nevertheless a very different notion since many inventions do not reach economic value. Innovation is based on invention, but not all inventions lead to innovations. Commercialization is the process by which an idea or invention is transformed into a product or service. But on closer examination, equation (4) should be written as follows:

$$
\text { Innovation }=\text { Invention } \times \text { Commercialization }
$$

Because, as summarized in Table 1, if there is an invention and no commercialization, there is no invention. Just as there is no invention if there is commercialization and no invention.

Table 1. Value of Innovation as A Product of Invention and Commercialization

\begin{tabular}{ccc}
\hline Invention & Commercialization & Innovation \\
\hline 0 & 0 & 0 \\
1 & 0 & 0 \\
0 & 1 & 0 \\
1 & 1 & 1 \\
\hline
\end{tabular}

Equation (1) is not free from criticism as evidenced by the following points:

First, we must not systematically adopt what is new for the simple reason that it is new, just as we must not categorically reject what is old for the simple reason that it is old. In other words, the obsession with the new reflects a 
Belabes | Islamic Fintech: Archaeology of a Discourse

rejection of the old, just as the obsession with the old reflects a rejection of the new. The obsession with novelty brings to light Hannah Arendt's idea ([1954]1972, p.43-45) that there is an end to tradition because there is a crisis of modernity. In fact, modernity is not in crisis, it is a crisis (Guillaud, 2005, p.77).

Then, contrary to the statement of the philosopher Bernard Stiegler (2009) that "there is no innovation without invention, but there are many inventions that produce no innovation", there can be innovation without invention, not all inventions have to be translated into innovations, and few innovations are pure inventions. Most of the time, it is a combination of pre-existing elements. As Gabriel Tarde $(1899$, p.36) pointed out, "our innovations are mostly combinations of previous examples". So, when Steve Jobs launches the iPhone, all its components are already there: radio, programming, computer, battery, telephony, touch screen, icon interface. The success came from Apple's ingenious and seductive way of mixing these elements to create the desire of many customers. However, there is a common set of these two notions.

Moreover, innovation is temporary, lasts only a limited time, and is eventually popularized. As Gabriel Tarde (1890, p.328) points out: "It is because the innovations, brought about by the fashion trend have harmonized, that they have set themselves as a custom". He also writes: "There is no literary innovation that, when generalized, does not take on a classical air, i. e. traditional" (Tarde, 1900, p.369). In the frantic race to win market share, one innovation replaces another. As Gabriel Tarde (1902, p.157) pointed out, before Joseph Schumpeter ([1942]1984, p.116-117), through his notion of the creative destruction process, "the root cause of war-crises is an invention, an improvement, an innovation that has just hatched and which, to grow, must drive back any industry based on an old invention". The more rivalry for market share becomes fierce, the more insignificant the innovation tends to become. What really counts is knowing how to sell the product. It is not certain in these conditions that the product will always be profitable for the consumer, unlike the time when Gabriel Tarde (1895, p.137) lived, according to which "if competitors are harmed by these innovations, consumers will be favored".

Finally, the equation clearly refers to a classical vision of the market as a space where seller's offers and buyer's requests meet to carry out exchanges. It does not consider the progress of scientific research relating to the notion of market, in particular through the notion of "market arrangements", which emphasizes the temporal and longitudinal aspect of market activities (Callon, 2017, p.54), and leads, regarding the epistemological posture of observation and analysis, to consider the goods themselves as processes, which should be 
Belabes | Islamic Fintech: Archaeology of a Discourse

followed throughout their development. But has innovation always been associated essentially with the commercialization of new technologies?

\subsection{Deconstruction of The Notion of Innovation}

Innovation as a practice that reflects the idea of renewal and change has existed for centuries, but as far as the notion is concerned, it is something else. Indeed, initially, the notion of innovation has a very different connotation from that commonly accepted today: Innovation would be necessary, a good thing in itself. However, the history of the notion shows that this has not always been the case. Until the 18th century, innovation was a contested word or at least one that aroused a certain reservation. It is not considered good in itself, it can be both profitable and "harmful" (Mondon, 1817, p.3). This also applies to the word invention and what it covers. As Lao-Tzu rightly says, "the one who invented the boat also invented the shipwreck".

Originally, the word used was the verb "innovate", which dates to the 14th century. It derives from the word "innovare" which means "to renew, to change" in the lower Latin as indicated in the Dictionnaire Universel François et Latin (1752, 7, p.320). It then pointed to the idea of "introducing new things" (Boyer, 1768, 2, p.320). This verb was first used by lawyers, in the sense of adding a clause to an already established contract. This does not apply to the marriage contract because "one cannot innovate anything to one's prejudice" (Duperray, 1761, p.139). In the legal field, "an innovation must be agreed by all" (Boutry, 1836, p.10) because it is never accepted "without resistance" (Le Fèvre, 1816, p.1). The first use of the word innovation goes back to Francis Bacon (1841, p.32) in 1625: "Surely every medicine is an innovation, and he that will not apply new remedies must expect new evils; for time is the greatest innovator; and if time, of course, alters things to the worse, and wisdom and counsel shall not alter them to the better, what shall be the end?".

In the political field, innovation is associated with a questioning of the prince's power, the established order, in particular of the Political Constitutions. In his Essay on the revision of the charter, Gabriel Gabet $(1819$, p.4) refers to the obligation "to swear obedience to the constitution, to defend it against any attack, any innovation, any change, and to maintain it finally in all its integrity".

In the religious field, innovation is often associated with what is opposed to "tradition" (Lamartine, 1843, p.11), i. e. the questioning of the teachings set out in the sacred texts. In his book The canons of ecumenical councils: Their publication in France, Adolphe Tardif (1872, p.13) writes: "Ecumenical councils do not create new dogmas; they only acknowledge traditional and universal beliefs, their canons are therefore only declarative of the faith of Catholicity, 
Belabes | Islamic Fintech: Archaeology of a Discourse

they do not introduce any innovation into the Church, any change in its faith or its practices".

Until the 19th century, there were objections to the use of the word innovation. As Jean-Augustin Barral $(1875$, p.7) points out, "the word innovate means literally to bring an innovation, a change, and this innovation can be true or good, as false or bad, I renounce to use it". Most often, the word innovation is used for polemical purposes. Those who aspire to change in the political, religious, or social order are most often described as innovators. Little by little, innovation is gradually gaining in popularity. The dictionary of the French Academy defines the word as follows: "Introduction of something new in government, laws, an act, a belief, a use, a science" (Académie française, 1835,2 , p.39). In his book /l est un, Pavie $(1879$, p.4) refers to the emulation that has led nations "down the path of progress and progress to innovation". In his book L'art de bien voter, Sincère (1884: 5) mentions that "science benefits from innovation". Innovation is seen as a source of economic progress because it is associated with science and its technical effects. In his Study of German Patent Law, Joseph Bonnet (1902, p.77) notes that the notion of technical effect "refers to the new and particular or unforeseen result of a new innovation or application". Hence the word "technical innovation" (Bonnet, 1902, p.78). For his part, Eugène van Overloop (1920, p.22) notes about lace: "The only technical innovation consisted in the application of a more flexible and delicate method to the implementation of old processes".

This semantic evolution leads to questions about what innovation is, the inducing factor, how to theorize it (Sweezy, 1943) in reference to Schumpeter, to whom the notion of innovation is attributed in economic analysis. It is because of the existence or otherwise of innovation that Schumpeter ([1911]1935, p.102) explains the cyclical alternation of phases of economic growth or depression. At the same time, governments are putting in place economic policies, of which technological innovation is a major element, based on the idea that innovation is a new technology that finds a market.

If innovation has become a slogan, generally accepted as necessary and good for all humanity, what would happen if it were critically analyzed? Implicitly when most researchers are interested in innovation, their thinking is oriented in one way or another. This is reflected in questions such as these: Why has it become urgent to innovate? How to learn to innovate in an uncertain world? How to co-innovate with customers and suppliers? How to engage in open innovation? How to establish more effective innovation policies?

Innovation benefits from a positive bias that stems from a widely shared ideological construction. It is at the heart of national economies, the European Union, and international organizations like the OECD. Without it, no new 
Belabes | Islamic Fintech: Archaeology of a Discourse

products, services, or processes, and enterprises struggled to gain market shares, reduce costs, and increase profits. The question "Innovate or disappear" replaced William Shakespeare's question "To be or not to be". Each slogan has borne the marks of its era. Hence the need to approach the notion of innovation with critical thinking, but that is not as simple as it sounds.

First of all, it should be noted the performative character of the statements containing the word innovation that led to changes in the reality and practices they designate. Innovation has become the solution to any societal problem, to the point that very rarely is there any question about the real nature and origin of these problems. Once the word innovation is pronounced as if everything had been said or almost said. But is innovation really necessary to solve all problems? Certainly not because change can take place in several ways and in particular through reform (is/āh), refinement (tahdhīb), revision (tanqīh), adjustment (taqwim), purification (tasfiyah) (Belabes, 2019b, p.60).

Then, it is important to be careful about the representations, symbols, and signs that the word innovation conveys. Is it not associated with what is best for the whole of humankind through the use of disruptive technologies? Moreover, it is often added that true innovation is that of the first market introduction. The others are just imitations. In the collective memory, the real innovators are those who innovate first. Hence the dichotomy 'leader/followers'. There is therefore a dominant economic dimension behind the notion of innovation, which is the notion of competitiveness to occupy a dominant position on a given market. This is evidenced by The Competitiveness and Innovation Framework Program (2007-2013) of the European Commission which is meant to improve the competitiveness of European companies through innovation.

Finally, let us not forget that behind this keyword, there is an ideology that does not say its name (Miles et al., 2007). The intelligentsia has participated in the creation of such an ideology that innovation is understood in one way rather than another. However, an analysis of the notion over a long period shows that innovation has covered a diversity of meanings. It has only been a few decades since it became a watchword, an irreplaceable horizon, a panacea for solving all problems (Bontems, 2014). A first step in the right direction would be not to associate innovation solely with technology, because many innovation initiatives are organizational, social, civic, related to uses and applications. This leads to an exploration of the notion of social innovation, like food cooperatives or fair trade, that have brought about a systemic change in the life of local communities, and that of low tech or slow tech which is characterized by the implementation of simple and inexpensive technologies, accessible to all and easily repairable, using common and locally 
Belabes | Islamic Fintech: Archaeology of a Discourse

available means, including the reuse or recycling of objects and/or common materials.

\subsection{The Importance of The Notion of Social Innovation}

Social innovation consists of developing new responses to new or poorly met social needs under current market and social policy conditions, involving the participation and cooperation of relevant actors, including users and users. These innovations concern the product or service, as well as the mode of organization and distribution, in areas such as aging, early childhood, housing, and health, the fight against poverty, exclusion, and discrimination.

All these new forms of innovation are poorly considered in the support and financing measures to innovation. Social innovation is situated in this context and must be associated with all the measures that advocate a broader vision of innovation that is most often played out in proximity. These may sometimes include structural issues such as employment or housing, or emerging issues such as: the aging of the population (health, dependency), new forms of social exclusion (fuel poverty), environmental protection (management of water, waste, energy).

It is important to support the development of social innovation to meet the growing social needs that cannot be met by the market or public authorities alone that showed their limits during the covid-19 pandemic. Social innovation can be one of the levers for developing the creation of activities, employment, social cohesion, and meeting new social needs. It can also be a lever for changing the scale of social and solidarity economy policies. This brings up to date the importance of the principle of subsidiarity which aims at privileging the exercise of competencies in matters of organization of human life at the lower level as long as the higher level cannot act in a more effective way.

If a problem cannot be solved with the same type of thinking that created it, there is a need to vary the solutions so that the use of the same tool does not become counterproductive. The history of the awqāf since the construction of the Ka'aba, the mosque of $Q u b \bar{a}^{\prime}$, then that of the Prophet Muhammad (peace be upon him) in Medina (Zarka, 1947, 1, p.7) shows with hindsight that the future of human societies is in the genius of simplicity, the power of creativity, and the elegance of sobriety. While the creation of a waqf responds to a social need to improve the quality of life of creatures beyond the human species, the development of the solution does not necessarily involve technology, nor does it necessarily require funding. As noted by Steve Jobs: "Focus and simplicity. Simple can be harder than complex; you have to work hard to get your thinking clean to make it simple". 
Belabes | Islamic Fintech: Archaeology of a Discourse

Moderation in everything is the source of the greatest advancements for human beings to allow everyone to build his own world (milieu, Umwelt, fûdo 風土) (Berque, 2014). In its relation to the environment, the being is not an object, but a subject that actively interprets the environment to elaborate its own milieu. By dint of abstracting himself from the object-world, a modern man comes to risk suppressing himself. It has begun to do so by ravaging the environment that forms the basis of its own world for the benefit of a virtual world shaped for him by the giants of Silicon Valley. The one who does not take care of building his world leaves it to others to shape a world of their own in accordance with their vision of life.

\subsection{Towards Slow Technology}

Technological performance, pursued in principle, has gone a long way to eclipsing the reasons and purposes that justified it. However, it cannot in itself be sufficient to solve the problem of resources in the broad sense of the word and to restore the usefulness of Islamic finance, which, according to its theorists, is supposed to have the role of transforming savings into the financing of the real economy. Fintech must be thought of in terms of its longterm effects on the life of societies, but above all in the light of the goals set by these same societies, in particular the fight against inequalities in the distribution of wealth.

If technological performance constitutes a competitive advantage, as the prevailing discourse stipulates, it must be contained below its own counterproductivity in the sense of Ivan Illich ([1973]2009, 1, p.551-552): "The tool can grow in two ways, depending on whether it increases man's power or replaces it. In the first case, the person leads his own existence, takes control and responsibility for it. In the second case, it is finally the machine that wins". This calls into question the dehumanizing and alienating character of technology.

The concept of counter-productivity marks a considerable advance in the social sciences, and probably far beyond what Illich imagined. Because, if he saw the 'macro-social' importance of this - the fact that, in a society, the more important the means used, the further away from the desired result, instead of to move towards it - he underestimated its 'micro-social' fertility, particularly within the economic analysis itself.

While the realization that well-being is not so much linked to economic growth highlights the counter-productivity of economic growth, the shift to diversified lifestyles, where autonomy would play an increasing role at the expense of heteronomy, is neither raised nor discussed in Islamic finance circles, which continue to highlight the role of Islamic finance in economic development in its generally accepted meaning, despite successive criticisms 
Belabes | Islamic Fintech: Archaeology of a Discourse

since the appearance of the Rome group's report The Limits to Growth (Meadows et al., 1972) which made it possible to question with a new eye how to meet needs: Why produce? What to produce? How to produce?

This leads to a rethinking of innovation, orienting it towards the economy of resources, the preservation and restoration of ecosystems, access to vital everyday things by the greatest number of people. This 'low tech' approach encourages a new look at old techniques and know-how which, in their vast majority, were based on natural materials and required, under duress, little energy to serve local needs. It also allows us to take a different look at the solutions developed in the countries of the South, where the context requires finding solutions that are sober, robust, simple, repairable, and accessible to the greatest number of people (Bihouix et al., 2018, p.6).

\section{Conclusion and Recommendation}

\subsection{Conclusion}

If the archeology of the discourse on innovation in Islamic finance (Belabes, 2019b) has revealed a tautology, i.e. a repetition of the same meaning in different words, that is as follows: (1) Islamic financial engineering consists of innovating new products compatible with Maqāșid al-Shari'ah, (2) Innovation plays a major role in the development of Islamic financial engineering.

In the introduction to his Essays in Positive Economics, Milton Friedman (1953, p.11) noted that tautological formulas, as a language, "have an extremely important place in economics". The deconstruction of the discourse on Islamic fintech revealed the following: (1) The difference between classical Islamic finance and Islamic fintech lies in the mobilization of technological innovation in the field of finance, (2) The difference between Islamic fintech and conventional fintech is in the compatibility of Islamic financial products with Maqāṣid al-Sharīah.

Both discourses are based on the same postulate: Islamic finance is based on innovation, the essence of which is Islamic financial engineering closely linked to Maqāșid al-Sharīah. This is a ready-made tautological assertion that highlights a lack of intellectual rigor under the effect of the mimetic rivalry. If the discourse claims to be based on a specific world view (spezifische Weltanschauungen as the Germans say), what drives it is not different from what is commonly called conventional finance. On the contrary, it is driven by an exacerbated desire for convergence and similarity. Competition here refers to the desire to imitate the other to achieve the same thing or nearly so. This is reflected in the words of Sheikh Salah Kamel, founder of the al Baraka 
Belabes | Islamic Fintech: Archaeology of a Discourse

Banking Group, during a visit to the Islamic Economics Institute at King Abdulaziz University in Jeddah on 12 June 2014: "We imitate them simply so that they say that we are developed like them".

In addition, the archeology of the discourse raised a major theoretical pitfall where innovation is fundamentally associated with technology while the discourse on Islamic fintech often refers to two fashionable topics: Corporate Social Responsibility (CSR) and Sustainable Development Goals (SDGs). To ensure some conceptual coherence, it would have been more appropriate to use the notion of social innovation, which can take original forms in addressing social problems (defining the problem, identifying causes and solutions), and in implementing change processes, as they incorporate new practices and forms of assessment focused on improving quality of life and preserving biodiversity rather than on the growth of the gross domestic product. Activities that strengthen social cohesion and non-market economic activities should be encouraged for learning to live as well or better with fewer material resources and less technology local-structure-adapted.

Hence the usefulness of another notion, to deepen common reflection and stimulate exchanges, that of 'low technology' where it is not a question of eliminating technology, but rather of thinking differently so that human beings do not become slaves to technology, in the same way, that they should free themselves from the servitude of debt. Therefore, any subjection by technology, debt, or any other means, or technique to use a term dear to the engineering sciences, could only be unfair. However, if injustice can only reign where good men have given up, injustice calls for injustice. Technology must be held accountable for its actions and the consequences of its actions, which requires an ethical commitment from society as a whole.

\subsection{Recommendation}

Islamic finance actors can no longer confine themselves to waiting for what is in vogue in the world of finance to copy it by perfecting the form without upsetting the substance, ignoring the non-neutrality of digital technology that disrupts epistemological key features and creates new risks. This requires the development of a proactive approach that focuses on eliminating problems before they have a chance to appear beyond the dominant thinking patterns, around dichotomies such as East/West, Islamic/Non-Islamic, Economics/Fiqh, Halal (permissible)/Haram (forbidden), Maqāṣid (purposes)/Aḥkām (injunctions). In the humanities and social sciences, not everything is black and white. As the Riemann (1858) hypothesis states, some facts are neither true nor false, but undecidable. This means that in our relationship with the fields of knowledge made by humans, including mathematics, we are not confronted with a ready-made truth, but rather with questioning in constant 
Belabes | Islamic Fintech: Archaeology of a Discourse

movement to break the circle as was done by Johannes Kepler who discovered that the planets travel about the sun in elliptical orbits. What is important is to create connections with living milieus in all their diversity.

It is imperative to invest in local startups to innovate solutions that meet both the needs of users and the ambitions of organizations, in order of priority, while taking care not to destroy social structures, and allowing each person to develop its specific world. The method of design thinking will be welcome because it offers the opportunity to imagine solutions through the intersection of analysis, intuition, experimentation, and human connection.

The design thinking process enhances empathic creativity to the benefit of everyone away from the mainstream culture of the zero-sum game conveyed by the obsession with competitiveness: what one side wins is lost by the other side. In any case, the future remains open and there is no path traced by disruptive technology, as the engineers of Silicon Valley believe. To paraphrase the Spanish poet Antonio Machado (1875-1937): "the path is made by walking" (se hace camino al andar). The future is not what will be, but what we will do. 
Belabes | Islamic Fintech: Archaeology of a Discourse

\section{References}

Académie Française (1835). Dictionnaire de l'Académie Française. Paris: Imprimerie et Librairie de Firmin Didot Frères.

Ali, M., Raza, S. A., Khamis, B., Puah, C. H. and Amin, H. (2021). How perceived risk, benefit and trust determine user Fintech adoption: A new dimension for Islamic finance, Foresight, Vol. 23 No. 4, pp. 403-420.

Arendt, H. ([1954]1972). La crise de la culture. Paris: Gallimard.

Aulet, B. (2013). Lecture 2: What is innovation. MIT Open Course Ware. Massachusetts Institute of Technology. Fall, Retrieved June 7, 2021 from https://cutt.ly/mnmMvF3

Bacon, F. (1841). The works of francis bacon, lord chancellor of England. Volume 1. Philadelphia: Carey and Hart.

Barral, J.-A. (1875). L'œuure agricole de M. de Béhague. Paris: G. Masson.

Belabes, A. (2001). Compétitivité nationale: Archéologie d'une notion et d'un débat. Ph.D. Thesis in Economic analysis and Policy. Paris: The School for Advanced Studies in the Social Sciences.

Belabes, A. (2019a). The methodological paradox in the mainstream economic discourse. Journal of King Abdulaziz University: Islamic Economics, 32(3), 87-104.

Belabes, A. (2019b). Al-Ibtikār fi al-Qitā' al-Mālī: al-Mafhūm wa Ma'ālim Manhajiyah [The Notion of Innovation in Finance]. In A. M. Belouafi, F. A. Al-Bashir (Ed.). Tatwīr al-Muntajāt al-Mālīyah al-Islāmiyah [Design and Development of the Islamic Financial Products] (pp. 41-88). Jeddah: The Scientific Publishing Center, King Abdulaziz University.

Belabes, A. (2021a). Fintech and Maqāsid dichotomy under the prism of the non-neutrality of techniques. In Billah, Mohd Ma'Sum (Ed.). Islamic FinTech: Insights and Solutions (pp. 37-55). London: Palgrave Macmillan.

Belabes, A. (2021b). Designing a top master's degree in Islamic fintech: The cognitive bias to avoid, Special Report published in Islamic Finance News, 18(37), 19.

Berque, A. (2014). La mésologie, pourquoi et pour quoi faire ? Nanterre/La Défense: Presses universitaires de Paris Ouest.

Bihouix, P., Baume de Brosses, E., Besse, G., Darras, M., Désaunay, T., Gancille, J.-M., Groussin T., Guillermou, T., Keller, A., Lapierre, C., Roudaut, S., Sinaï, A., Soyer, M., Tassin, B., Vanhove, A. \& Viel D. (2018). Vers des technologies sobres et résilientes - Pourquoi et comment développer l'innovation 'low-tech'?. Paris: Fondation La Fabrique écologique. 
Belabes | Islamic Fintech: Archaeology of a Discourse

Billah, Mohd Ma'Sum (2021). Islamic fintech: Insights and solutions. London: Palgrave Macmillan.

Boer, H., \& During, W. E. (2001). Innovation, what innovation? A comparison between product, process and organizational innovation. International Journal of Technology Management, 22(1/2/3), 83-109.

Boltanski, Luc \& Chiapello, Eve (1999). Le nouvel esprit du capitalisme. Paris : Gallimard.

Bonnet, J. (1902). Étude de la législation allemande sur les brevets d'invention. Paris: A. Chevalier-Marescq.

Bontems, V. K. (2014). What does Innovation stand for? Review of a watchword in research policies. Journal of Innovation Economics \& Management, 15(3), 39-57.

Bouleau, N. (2014). La modélisation critique. Versailles : Quae.

Boutry, J.-B. (1836). Droit français: du bail à Cheptel: du contrat de société. Paris: Imprimerie de Moquet.

Boyer, A. (1768). The royal dictionary English French and French English. Lions: John Mary Bruyset Bookseller.

Callon, M. (2017). L'emprise des marchés. Comprendre leur fonctionnement pour pouvoir les changer. Paris: La Découverte.

Carney, M. (2016). Enabling the fintech transformation - revolution, restoration, or reformation?. Speech by the Governor of the Bank of England and Chairman of the Financial Stability Board, at the Lord Mayor's Banquet for Bankers and Merchants of the City of London, Mansion House, 16 June, Retrieved June 7, 2021 from https://cutt.ly/dnmMInD

De Vauplane, H. (2015). Fintech: les nouveaux acteurs de la finance. Revue $d^{\prime}$ Economie financière, 118, 27-35.

Descartes, R. (2008). Discours sur la méthode. Paris : Garnier \& Flammarion.

Dictionnaire Universel François et Latin (1752). Paris: Compagnie des Libraires Associés.

Duperray, M. (1761). Traité des contrats de mariage. Paris : Chez Prault père Imprimeur.

Dyson, G. (2015). La technologie possède les qualités que nous cherchons dans la religion, Entretien réalisé par Antoine Vivianie. L'OBS avec Rue89, 26 août.

Estabil, J. (2012). Entrepreneurship and innovation: MIT History and Observations. In the workshop Developing innovative technological entrepreneurship at the universities. MIT, 22-23 February. 
Belabes | Islamic Fintech: Archaeology of a Discourse

Fagerberg, J. (2003). Innovation: A guide to the literature, centre for technology, innovation and culture. Oslo: University of Oslo.

Foucault, M. (1969). Archéologie du savoir. Paris : Gallimard.

Gabet, G. (1819). De la révision de la charte. Dijon: Imprimerie de Carion.

Guillaud, F. (2005). La modernité: crise d'adolescence de I'humanité?, Le Philosophoire, 25(2), 77-88.

Haenni, P. (2006). Islam de marché. Paris: Seuil \& La République des idées.

Illich, Ivan ([1973]2009). CEuvres complètes, Paris: Fayard.

Lafley, A. G., Charan, R. (2008). The game changer: How every leader can drive everyday innovation. London: Profile Books Ltd.

Lamartine, A. de (1843). L'État, l'Église et l'enseignement. Mâcon: Impriemerie de Chassipollet.

Le Fèvre, D. J. C. (1816). Réflexions d'un citoyen qui n'est ni rentier, ni propriétaire de biens nationaux, ni créancier de l'État, et encore moins capitaliste, sur la vente des quatre cent mille hectares de bois nationaux et de biens communaux. Paris: Imprimerie de Mme veuve Agasse.

Meadows. D., Meadows, D., Randers J. \& Behrens, W. W., III. (1972). The limits to growth. New York: Universe Books.

Miles, R. E., Snow, C. C. \& Miles, G. (2007). The ideology of innovation. Strategic Organization, 5(4), 423-435.

Mondon, G. (1817). Un petit mot sur l'abus du sulfure de potasse dans les eaux thermo-sulfureuses de Bagnères-de-Luchon. Toulouse: Bénichct Cade.

Morse, K. (2013). Innovation is invention plus commercialization. Interview BBVA Innovation Center. EmTech España 2013. Valencia.

Noble, D. F. (1999). The religion of technology: The divinity of man and the spirit of invention. New York: Penguin Books.

Pavie (1879). Il est un. Brionne: Imprimerie V. Daufresne.

Rameix, G. (2016). Discours, forum fintech AMF / ACPR: Speech by Gérard Rameix, July 18, Retrieved June 7, 2021 from: https://cutt.ly/gnmMNA9

Riemann, B. (1858), Über die anzahl der primzahlen unter einer gegebene grösse [on the number of primes less than a given magnitude], Monatsberichte der Königlich Preuÿischen, Berliner Akademie der Wissenschaften, 671-680.

Roberts, E. B. (1988). Managing invention and innovation. Research Technology Management; 31(1), 11-29. 
Belabes | Islamic Fintech: Archaeology of a Discourse

Rabbani, M.R.; Bashar, A.; Nawaz, N.; Karim, S.; Ali, M.A.M.; Rahiman, H.U.; Alam, M.S. (2021). Exploring the Role of Islamic Fintech in Combating the Aftershocks of COVID-19: The Open Social Innovation of the Islamic Financial System. Journal of Open Innovation: Technology, Market, and Complexity, 7(136). https://doi.org/10.3390/joitmc7020136

Sánchez Fernández, S. (2021). Islamic fintech. London \& New York: Routledge.

Schumpeter, J. A. ([1911]1935). Théorie de l'évolution économique. Recherche sur le profit, le crédit, l'intérêt et le cycle de la conjoncture. Paris: Dalloz.

Schumpeter, J. A. ([1942]1984). Capitalisme, socialisme et démocratie. Paris: Payot.

Sincère (1884). L'Art de bien voter. Troyes: Imprimerie du Petit Troyen.

Simmel, G. ([1912]1998). La religion. Paris: Circé.

Stiegler, B. (2009). Il y a beaucoup d'inventions qui ne produisent aucune innovation, Propos recueillis par Catherine Portevin. Télérama, 5 juin.

Supiot, A. (2015). La Gouvernance par les nombres. Paris : Fayard.

Sweezy, P. M. (1943). Professor Schumpeter's theory of innovation. The Review of Economics and Statistics, 25(1), 93-96.

Tarde, G. (1890). Les lois de l'imitation: étude sociologique. Paris : F. Alcan.

Tarde, G. (1895). Essais et mélanges sociologiques. Paris: A. Storck - G. Masson.

Tarde, G. (1899). Les lois sociales: Esquisse d'une sociologie. Paris : F. Alcan.

Tarde, G. (1900). La philosophie pénale. Lyon: A. Storck.

Tarde, G. (1902). Psychologie économique. Paris : F. Alcan.

Tardif, A. (1872). Les canons des conciles œcuméniques: leur publication en France. Paris: V. Palmé.

Toynbee, A. (1978). L'histoire. Bruxelles: Elsevier Sequoia.

Toynbee, A. ([1956]1963). La religion vue par un historien. Paris: Gallimard.

Van Overloop, E. (1920). La dentelle: Guide du visiteur. Bruxelles: Musées royaux des arts décoratifs et industriels.

Zarqa, M. (1947). Ahkām al-Awqāf. Damascus: Matba'at al-Jāmi’a al-Sūriyyah. 
Belabes | Islamic Fintech: Archaeology of a Discourse

This page is intentionally left blank.

International Journal of Islamic Economics and Finance (IJIEF), 5(1), 129-150 | 150 